\title{
РЕЛИГИОВЕДЕНИЕ
}

\author{
UDC $141.82+2-1+001$
}

\section{Significance of a religion in the Petr Bitsilli's research works}

\author{
D. I. Weber \\ St. Petersburg State University, \\ 7-9, Universitetskaya nab., St. Petersburg, 199034, Russian Federation
}

For citation: Weber D. I. Significance of a religion in the Petr Bitsilli's research works. Vestnik SPbSU. Philosophy and Conflict Studies, 2018, vol. 34, issue 1, pp. 115-121.

https://doi.org/10.21638/11701/spbu17.2018.111

The study is devoted to the analysis of creativity by Petr Mikhailovich Bitsilli, a historian who worked both in Russia and abroad, on the study of religion. The notion of "mentality" refers us to the traditions of the "new historical science" that arose in France in the late 1920s. However, it seems that long before this an anthropologically oriented tradition had developed in Russia. Within its framework there are studies revealing various aspects of the history of the Western European Middle Ages, but this tradition had dedicated itself especially to the individual and ultimately to his culture, way of life, customs, beliefs and so forth - what is customarily called everyday life. These works do not aim to directly study religious experience, religiosity, religion as such, but they prove to be invaluable to the researcher of religion precisely because of his "impartiality" with regard to religious subjects. In this context we can conditionally distinguish two main directions of the research work of Bitsilli. The first is the place of religion in the conditions of change of historical epochs, and the second being religiosity as a cultural and historical phenomenon. It is important to note here that research related to religious issues refers to the early period of his scientific activity. He developed an image of a medieval man from several elements, singling out and characterizing, at the same time, a much larger number of constituents of his mentality. The sources used by the researchers are similar. They were the lives of saints, literary monuments of the era, the writings of mystics and theologians, "visions" the protocols of inquisition. Bitsilli studied the writings of many prominent theologians and philosophers of the era. Relying on the texts of medieval chronicles, in particular, on the literary heritage of Salimbene, Petr Bitsilli reconstructed the religious consciousness of a medieval man.

Keywords: Bitsilli, religion studies, medieval culture, religiosity.

The national historical studies classified the history of the West European Middle Ages as a specific part of study in the second half of the $19^{\text {th }}$ century to the beginning

( Санкт-Петербургский государственный университет, 2018 
of the $20^{\text {th }}$ century. At that time the scientific background was laid, the first specialists emerged in that domain, and separate medieval history departments were opened at the universities.

In the meantime, at the turn of those centuries and in subsequent years, history was experiencing a severe crisis traditionally associated with a paradigm shift in history, a search for new methodological principles and methods of cognition, and changes in the social status of historical studies. The dramatic events in the early $20^{\text {th }}$ century and the overall severe social and economic state of the country affected, either directly or indirectly, the frames of mind, having intensified downbeat moods. History manifested an enhanced interest in religious philosophy, history of religion and religious thought, and the peculiarities of religious worldviews in different historical eras.

A particular interest in religious consciousness of the medieval man was manifested by Petr Bitsilli. Within the period of the years 1911 to 1920, this researcher lectured at the Imperial Novorossiysk University in Odessa [1, p.71], then in Skopje between 1920 and 1924, and later at the Sofia University in Bulgaria [2, p. 21; 3, p. 91-92].

His works gained attention due to his special outlook on the place of the history of religion, having interlaced the latter with the world history [4, p. 204; 5, p. 34]. Thus, he considered the $18^{\text {th }}$ century as a gradual and inevitable resolution of "delusions": "one day - either earlier here or later there - people wake up and shift from delusions to the "Sound Mind", to the "truth" which is wherever and always self-identical" [6, p. 32]. This concept of the age of Enlightenment differed from the positivism of the $19^{\text {th }}$ century solely by the missing reference to the evolutionary and consistent nature of such transformations [7, p. 99]. Upon approval of the aforementioned trends under the status of laws, a new scientific discipline was institutionalized, i.e. the comparative history of religions. It was intended to: a) apprehend the psychology of religious phenomena based on various materials, provided that the compared facts are attributed to the same stages of cultural development, and b) generate an ideal history of the human spirit development, in the framework of which separate empirical histories would constitute fractional manifestations [8, p. 222]. However, the comparative history of religions is unable to discern a remarkable synchronism in the religious and philosophic development of virtually all cultural milieus.

Petr Bitsilli noted that in the $6^{\text {th }}$ century B.C. a single and conscious shift from naturalistic cults to monotheistic doctrines formed the basis of the process of civilization: in India Buddha was preaching, in China Confucius and Lao-tzu, in Persia Zoroaster, Hellas was marked by the religious reform of Pythagoras, the development of rationalistic theism of Anaxagoras and mystic teachings of Heraclitus about the Logos, and others. "Unity of the history of spiritual development in the Old World can be traced even further. Just assumptions can be made with regard to any reasons for the indisputable similarity of mental development in Hellas and China during the same historical period. It's tough to tell the extent, to what the Hindu theophany religious philosophy affected the Middle East gnosis and the theophanism of Plotinus, in other words, the religious philosophy of Christianity; however, the fact of such influence can hardly be denied. Messianism and eschatology, one of the core aspects in the Christian worldview, which maybe mostly contributed to the European thought, were inherited by the Judaism from Iran" [6, p. 34]. The unity of the world history affects also the advancement of great historical religions. Mithraism appears in Rome exactly at the time of the rise in Christian preaching. Christianity advances 
in the Orient via the great trade routes, the same along which Buddhism previously advanced, whereas later Islam. Nestorian Christianity was widely-spread across the Orient up to the $13^{\text {th }}$ century, when importunate activities conducted by the western missionaries were contributing to the rejection of Christianity and the growth of Islam and Buddhism. The easy and rapid development of the great spiritual movements in the Old World was conditioned, to a considerable extent, by the tolerant attitude of people in Central Asia, providing for transcultural interference.

Thus, such single history existed long before its conceptualization in the age of Enlightenment. The thesis of genesis thereof in the Age of Discovery is a mere Eurocentric myth [9, p. 106]. Bitsilli means that the fashionable idea of a "single world religion constitutes the same bad taste as the idea of an "international language", a result of misunderstanding the essence of culture, which always happens and never is "done"; therefore, it is always individual" [6, p. 36]. Such tendency to individualize any historical materials is due, probably, to the traditions elaborated by the school of Ivan Grevs [10, p. 214-215].

In his work on the theory of historical Studies, the researcher states an important methodological principle, pursuant to which any rationalization of history, any attempts to frame it under some metaphysic basis exclude the moments of fortuity and irrationality in the history. Eventually, any issues which don't fit the "pattern" in real history have to be sacrificed in favor of an ideal history, some sort of abstraction. In the researcher's opinion, any modeling of history is vicious, while any reconstruction thereof is subjective and lacking effect [11, p.27]. However, the issue of any criteria in the history intended to put in order the chaos of givenness remains open in the "Essays..." In his work Petr Bitsilli points out that "the environment is created by the person quite as much, as the person is shaped by the environment" [12, p.131-132], hence, any historian must take into consideration both objective and subjective factors of historical development.

The expressed statements are similar to the ideas of Lew Karsavin, who considers that the subject matter of historical studies must include research into humanity in the framework of its social development, which itself constituted a derivative element of mental development, the needs of "Self". To study such social and mental processes, it is necessary to apply the method of compassion and empathy, constituting the basis of historical reasoning. However, in the historian's opinion, it must thus be necessary to avoid the "framing of any other mental process by analogy to the 'mine' and solely out of 'mine"' [13, p. 112]. A similar idea can be traced in the works of Petr Bitsilli: "We think, hence, speak essentially otherwise than people of the $12^{\text {th }}$ and $13^{\text {th }}$ centuries. Those wishing to understand, as far as practicable at all, a stranger's thought maintaining its clarity and singularity, shall grasp such thought in its own verbal covering" [12, p. 4], since the "mental world of humans in the past times differs from the mental world of contemporary man not only in content, but also in form" [12, p. 132].

Thus, the historians stated a significant thesis in the historical anthropology, assuming that man is an important entity within the historical process, whereas his personality and worldview vary in the course of historical development under the influence of a certain epoch and social milieu; therefore, mental history requires a specific research methodology.

Petr Bitsilli structures the image of medieval man in its work "Elements of Medieval Culture". Similar to Lew Karsavin, he structured the image of medieval man out of several elements, having highlighted and characterized it rather more as constituents of its 
mentality. The sources used by the researchers are also similar. These included the lives of saints, literary masterpieces of the epoch, the writings of mystics and theologians, the "visions", and the inquisition protocols. Bitsilli studied the writings of many prominent revelators and philosophers. Proceeding from the texts of medieval chronicles, in particular, the literary heritage of Salimbene, Petr Bitsilli reconstructed the religious consciousness of medieval man [14, p. 12]. Thereat, he stated an important observation: the spiritual development of medieval man was significantly affected by the catholic practice of confession, which formed the habit of self-observation and self-analysis.

In this work of Bitsilli the author analyzed the chronicles of the Franciscan Salimbene. The researcher was not the first to address this source [15, p. 208-209]. However, he was the first person to focus attention on the author of the chronicles, but not on the events described therein. The chronicles were already subject to the consideration by historians of the $19^{\text {th }}$ century. For example, Oswald Holder-Egger's intention was to provide the internal story of Salimbene [16, p.2-7], the history of his spirit within the external biography. Nonetheless, it is highly fragmented. In addition, the researcher noted that it is impossible to restore the real biography of Salimbene, based on the data he gives about himself. Bitsilli agreed with this point. That, perhaps, made him reword the objective of the research. "I am taking the internal "Self" of Salimbene, not as a cross section - when he being in his fifties, began writing the chronicles. To study the order of his thoughts, his beliefs, inclinations, wishes and ideals - that was the aim I have set" [14, p. 235].

The author is convinced that regardless of the segment of history studied its result is the address to a personality. As to the economic, idea-driven and other factors, they, according to the author, are significant only because they are reflected in the consciousness of separate persons, becoming motives, directing their activities. Therefore, Bitsilli's aim was to study Salimbene's life circumstances, but not the social structures, though he did not reject their significance. The consideration is therefore important because we apply the received data to the contemporaries.

In other words, for Bitsilli it was important to understand the spiritual bases of the time via the study of the pre-determined and unique personality. According to Kravchenko, the study of the everyday world suggested by Bitsilli shows the development of the specific historic social objective reality via constructing, generating meanings within the personal experience flow. This methodological setting creates opportunities to reconstruct cultural universe of the time. The unique one that is called by Bitsilli the "Zeitgeist" following J. Herder [17, p. 178]. In law and moral, religion and art, in the structure the "subject reveals the Self, reflecting externally his internal essence and enriching the given world with the results of creative processing the elements, perceived from this world" [6, p. 110].

Petr Bitsilli repeatedly brings the reader back to the thought of the inner dialectics of consciousness. If a researcher of culture takes it into consideration, it does not allow absolutizing any overall uniqueness of the personal inner world for a specific epoch. Such fallacies are quite probable, especially taking into account the fact that a special focus of the European historic science to the Medieval culture was related to the belief that it had to contain the roots of the European individualism [10, p. 214]. Petr Bitsilli reminds that individualism is a specific feature of historic thinking in general, but its specific historic manifestations are determined by cultural features of the specific historic period. Mysticism was such a manifested feature for the European Middle Ages: "Individualism was not 
generated by mystics, since the latter itself is a form of individualistic manifestation. These phenomena are rather explained by the overall cultural growth in the $11^{\text {th }}-$ early $12^{\text {th }}$ centuries. It is inappropriate to specify the reasons of this rise, but it is worth dwelling on its features and seeking to discover its special characteristics"; i. e. a synchronic description, but not diachronic development, which reflects methodological proximity of this cultural research to the view on the static historian, represented in the introduction to the "Basics to the Medieval religiousness" [6, p. 107].

Bitsilli's interest in the personality is brightly shown in his rejection of Karsavin's idea of the typicality of a genius for his or her epoch, which, according to Karsavin, generates the genius as a voicer of average, but far more intensive than average features. This idea, interesting by itself, inevitably led the author to ignoring a personality in favour of studying the general "religious fund". Karsavin was perfect in "living into" the personality in question, but if the purpose of his living-in was the need to see the representation of the General in the individual, it definitely forced the author to ignore the search for individual uniqueness. This is explained by the search for identifying acceptable theoretical grounds for historic synthesis, which must include some features common to any historic epoch, which ensure theoretical unity of the historic process. Karsavin is justified in these generalizations by the fact that this search was typical of the Medieval and Renaissance thinkers. This brings historic value to his historic constructs. And from the standpoint of the culture history interests, Karsavin's idea of the correlation between the prominent and typical in the historic research was appreciated only by Petr Bitsilli. Moreover, he appreciated it as a fellow-thinker in historic interests. Nevertheless, he found it possible to notice the subsequent neglecting personality in history.

Similarities and differences between his studies and research done by L. P. Karsavin were admitted by Petr Bitsilli himself in his introduction to Salimbene: "Taking the spiritual uniqueness of one thirteenth-century man to test, in fact I pursued the same goal as the one studied from another end, so to say, by the author of the "Basics to religious life". Analyzing Karsavin's techniques, I did not mean to reveal their fallaciousness (vice versa, I consider them generally accurate). In essence I was willing to prove the validity of mine. We should sincerely admit that any one studying a personality to characterize his or her epoch can do the work only provided he or she already has a given image of this epoch.

The researcher considered that the central "governing" idea of the Middle Ages was the longing for universality, meaning by that concept the endeavor to "cover the world in its entirety, apprehend it as some kind of completed unity", wherein "there is no room for any opinions or private judgments, there is only "truth", and any truth is a dogma" [14, p. 124]. Petr Bitsilli distinguished two conditions for the unity of world order in the consciousness of medieval man: symbolic character and hierarchical pattern, meaning that the world is conceived as a hierarchy of symbols [14, p. 53]. The historian affirms that medieval people were not imagining the world as symbolic, but perceived it as such. "They were speaking symbolically, $\langle\ldots\rangle$ they didn't understand any speech at all, other than the symbolical" [14, p. 85-86]. Symbolism and hierarchism is the formula of the medieval worldview and the whole medieval structure [14, p. 13]. This ideas we can see also in Bitsilli's review on Fedotov's work "Saints of Ancient Russia" [7, p. 106].

Bitsilli concluded that the medieval worldview had a static and universal character, notwithstanding the diversity of its external manifestation thereof and so postulated the 
unity of medieval culture as a result of its absolute subjection to the single center - the church. Thus, religious commitment constituted a specific reason and grounds for universality of the medieval society.

Thus, having emerged in the first half of the $20^{\text {th }}$ century, the national medieval studies proved to be responsive to cultural researches, including the history of both spiritual and material culture. The researcher concerned herein addressed also the intricate place of religion within the context of culture. On the one hand, it represented certain reflection, and on the other hand, it constituted an important indicator of shift between the historical epochs. In other words, acting in the capacity of historian, Bitsilli went, to a certain extent, beyond the scope of historical positivism towards another domain proximate to cultural anthropology.

\section{References}

1. Sachenko V. A. Odesskij period tvorchestva P. M. Bicilli: stanovlenie filosofa [Odessa period of creativity PM Bitsilli: the formation of a philosopher]. Naukovij Visnik Mizhnarodnogo gumanitarnogo universitetu, 2011, no. 2, pp. 71-74. (In Russian)

2. Kuramshina Ju.V. Tvorchestvo Petra Mihajlovicha Bicilli v otechestvennoj istoriografii [Creativity of Pyotr Mikhailovich Bitsilli in Russian Historiography]. Kul'tura narodov Prichernomor'ja, 2005, no. 68, pp. 20-23. (In Russian)

3. Dodonov R. A. Kritika Petrom Bicilli filosofii Evrazijstva [Criticism of the philosophy of Eurasianism by Peter Bicilli]. Gumanitarnij visnik Zaporiz'koj derzhavnej inzhenernej akademii, 2013, no. 52, pp. 218226. (In Russian)

4. Grigorova D. Petr Bitsilli i evraziystvo. [Peter Bitsilli and Eurasianism], Bulgarite v Severnoto Prichernomorie. Izsledvaniya i materiali [The Bulgarians in the Northern Black Sea coast. Research and materials], 2009, vol. 10, pp. 303-308.

5. Konovalov I. N. P. M. Bitsilli i evraziistvo: kontseptual'nye podkhody k resheniiu problemy v sovremennoi istoriografii [P.M. Bitsilli and eurasianism: conceptual approaches to solving the problem in modern historiography], Curriculum Vitae. Collection of papers, 2010, issue 2, pp. 34-37. (In Russian)

6. Bitsilli P.M. Elementy srednevekovoi kultury [Elements of medieval culture]. St. Petersburg, Mifril Publ., 1995. XXVIII, 244 p. (In Russian)

7. Karsavin L. P. Vvedenie v istoriiu [Introduction to History]. Voprosy istorii, 1996, no. 8, pp. 101-127. (In Russian)

8. Bitsilli P. M. «Vostok» i «Zapad» v istorii Starogo Sveta ["East" and "West" in the history of the Old World]. Rossiia mezhdu Evropoi i Aziei: evraziiskii soblazn. Moscow, Nauka Publ., 1993, pp. 24-35. (In Russian)

9. Mjør K. J. Reformulating Russian: the cultural and intellectual historiography of Russian first - wave émigré writers. Leiden, Brill, 2011. 327 p.

10. Karpova A. O. Religioznaia mental'nost' kak predmet otechestvennoi medievistiki vtoroi poloviny XIX - nachala XX vv. [Religious mentality as a subject of national medieval studies of the second half of the $19^{\text {th }}$ and early $20^{\text {th }}$ centuries]. Vestnik LGU im. A. S. Pushkina, 2012, no. 1, pp. 211-219. (In Russian)

11. Bitsilli P. M. Ocherki teorii istoricheskoi nauki [Essays on the theory of historical science]. Praga, Plamia Publ., 1925. 339 p. (In Russian)

12. Bassin M., Glebov S., Laruelle M. Between Europe and Asia. The origin, theories and legacies of Russian Eurasianism. Pittsburg, University of Pittsburgh Press, 2015. 280 p.

13. Vasileva M. Bitsilli Petr Mikhailovich. [Bicilli, Pyotr Mikhailovich]. Russkoe zarubezhe. Zolotaia kniga emigratsii. Entsiklopedicheskii biograficheskii slovar' [A Russian abroad. Golden book of emigration: Encyclopaedic Biographical Dictionary]. Moscow, ROSSPEN (Rossiiskaia politicheskaia entsiklopediia), 1997, pp. 90-92. (In Russian)

14. Bitsilli P. M. Salimbene. Ocherki ital'yanskoj zhizni XIII v. [Salimbene. Essays on the Italian life in $13^{\text {th }}$ century]. Odessa, 1916. 389 p. (In Russian)

15. Levchenko V. A. Kul'tura kak dukhovnyi kontekst epokhi v rabotakh P. M Bitsilli [Culture as the spiritual context of the era in the works of P. M. Bitsilli]. Germenius. Odessa, 1999, pp. 207-220. (In Russian) 
16. Holder-Egger O. (ed.) Cronica fratris Salimbene de Adam ordinis Minorum. Zechnall, Stuttgart, 1963. XXXII, 755 p.

17. Herder J. G. Kritische Wälder oder Betrachtungen, die Wissenschaft und Kunst des Schönen betreffend, nach Maßgabe neuerer Schriften [Critical forests or reflections concerning the science and art of the beautiful, according to more recent writings]. Hartknoch, Riga, 1769. 278 p.

Received: 23.06.2017

Accepted: 03.10.2017

Author's information:

Weber Dmitriy I. — PhD; d.veber@spbu.ru

\section{Значение религии в исследованиях Петра Михайловича Бицилли}

\section{Д. И. Вебер}

Санкт-Петербургский государственный университет,

Российская Федерация, 199034, Санкт-Петербург, Университетская наб., 7-9

Для цитирования: Weber D.I. Significance of a religion in the Petr Bitsilli's research works // Вестник СПбГУ. Философия и конфликтология. 2018. Т. 34. Вып. 1. С. 115-121. https://doi.org/10.21638/11701/spbu17.2018.111

Исследование посвящено анализу творчества Петра Михайловича Бицилли, историка, трудившегося как в России, так и за рубежом. Можно условно выделить два основных направления исследовательской работы П.М.Бицилли. Первое - место религии в условиях смены исторических эпох, второе - религиозность как культурно-историческое явление. При этом важно заметить, что исследования, касающиеся религиозных вопросов, относятся к раннему периоду его научной деятельности. Он сформировал образ средневекового человека из нескольких элементов, выделяя и характеризуя вместе с тем значительно большее число составляющих его менталитета. Данное понятие связано с традициями Школы хартий, возникшей во Франции в конце 20-х годов ХХ в. Взгляды одного из представителей отечественной историографии, в рамках которой появляются исследования, раскрывают различные религиозные аспекты истории западноевропейского Средневековья. Однако они посвящены главным образом человеку, его культуре, быту, нравам, верованиям и т. д. Таким образом, они подпадают под историю «ментальности», или «историю повседневности». Эти работы не ставят своей целью непосредственное изучение религиозного опыта, религиозности, религии как таковой, однако оказываются неоценимым подспорьем для исследователя религии именно в силу своей «непредвзятости» в отношении религиозных сюжетов. Отмечаются некоторые общие черты с работами Л.П.Карсавина. Сходны и источники, которыми пользуются исследователи. Ими были жития святых, литературные памятники эпохи, сочинения мистиков и теологов, видения, протоколы инквизиций. Бицилли изучил сочинения многих видных богословов и философов эпохи. Опираясь на тексты средневековых хроник, в частности на литературное наследие Салимбене, П.М. Бицилли реконструировал религиозное сознание средневекового человека.

Ключевые слова: Бицилли, изучение религии, средневековая культура, религиозность.

Контактная информация:

Вебер Дмитрий Иванович - канд. ист. наук; d.veber@spbu.ru 